PAedagogia Christiana

I/43 (2019) - ISSN 1505-6872

\title{
Carina Rossa, Viviana Carlevaris Colonnetti (eds.), Custodiar la infancia: Promoción del bienestar y la protección integral de niños y adolescentes, Buenos Aires: Editorial Ciudad Nueva, 2018, 170 pp.
}

DOI: http://dx.doi.org/10.12775/PCh.2019.033

The beginning of the new millennium brought into the Catholic Church and other circles a heated discussion concerning the painful matter of sexual abuse of children and minors. After the first wave of revelations about the phenomenon of sexual abuse carried out by the people of the Church in the United States during the pontificates of Benedict XVI and Pope Francis, fresh cases were disclosed. In response to the issue, the Focolare Movement set up the Central Commission for the Promotion of Welfare and Protection of Children and Adolescents (Commissione Centrale per la Promozione del Ben-essere e la Tutela dei minori), which drew up guidelines regulating the sphere of contact with minors ${ }^{1}$. This volume is an introduction to the issue of protection of minors from sexual abuse. Knowledge and experience are shared by specialists in the fields of medicine, psychology, pedagogics, and law.

The first part examines the needs of children and youth that stem from inalienable rights rooted in human dignity. It also discusses pedagogical principles and didactic criteria for the integral and safe development of young people. The central part of the book addresses specific issues of the Catholic Church's response to the issue of sexual abuse, the psychological aspects of violence against children and minors, the implementation of the UN Convention on the Rights of the Child, and sociological research into the

${ }^{1} \mathrm{https}$ //www.focolare.org/download/linee-guida-focolari-tutela-minori/?wpdmdl= 171233 \&ind $=1542193940666$ 
sexual exploitation of minors in the world. The work culminates with a practical component developed by the Central Commission for the Promotion of Welfare and Protection of Children and Adolescents: a handbook applying the general principles laid down in the previous chapters. At the end of each chapter, a graphically distinct synthesis of the main ideas of a particular part of the book is presented. This provides questions for reflection and identifies criteria for evaluating educational centres.

The whole book is preceded by a Foreword by the Secretary of the Congregation for Christian Education, Archbishop A. Vincenzo Zani.

Proper discernment of the needs of the child, and satisfying those needs, leads to a good understanding of children's rights. According to paediatrician Raffaele Arigliani, we are faced with a correlation between needs and rights (pp. 26-27); these should include the need/right to be heard, to trust, to be motivated, to be supported, to time, and to have the rules of life explained. Of course, the first months of life are the most important in shaping a child. Naturally, after this initial period, the child enters a broader community that fulfils the pedagogical and formative function. It is important to ensure optimum development, which must be done at the level of biological existence and in the psychological, social, and spiritual dimensions. One must remember that each child needs to learn standards of behaviour. A child learns not according to what the educator "wants it to be", but what he/she actually is (p. 17). The Ugandan proverb quoted by psychologist Carina Rossa, "It takes a tribe to raise a child" (p. 30), is a precious reminder of the need for an educational community. This broadly understood community is connected with family, school, parish, groups of belonging, and place of residence. It creates a network of relationships that help to define the young person, especially where interpersonal space is respected (pp. 33-34). Diverse educational entities should cooperate harmoniously, demonstrating unconditional acceptance of the persons concerned. It is necessary to teach students how best to communicate their experiences, and equip them with the assertiveness they need to protect their own intimate and social spaces and group activities (pp. 44-46).

Acknowledging the painful fact of the sin of sexual harassment of children and youth by the people of the Church, Neva Cifuentes Celedón - integral formation adviser to the Archdiocese of Concepción in Chile - points to the need for accountability and active interventions against evil. The Church has undertaken, at various institutional levels, a lot of hard work to try to come to terms with the past on the one hand, and on the other, to ensure a secure space in its community for children and youth. 
The process of formation of candidates for the priesthood remains crucial. But it is also necessary to pay attention primarily to their proper education and development as humans (p. 56).

The typology of violence against children and minors occupies the central chapter of the book, although this topic is analysed thoroughly in the book generally. It includes physical, psychological, and domestic violence, as well as educational pathologies, sexual abuse, and bullying (pp. 65-83). Research by the World Health Organization, cited by psychotherapist Viviana Carlevaris Colonnetti, shows that one-quarter of surveyed adults have experienced physical violence in their childhood. It states that $20 \%$ of women and $7 \%$ of men were sexually abused in childhood (p. 64). The social problem is therefore vast, especially in view of the fact that the perpetrators of these offences are mostly individuals within the close family circle. According to Professor Colonnetti, these pathological phenomena will become less frequent when responsible parents abandon violence in raising their children and create a personal bond with their offspring (p. 87). Negative outcomes of violence affect the majority of victims. It has to be emphasised, however, that children who are victims of violence and pathology in family relationships have the ability to overcome the trauma in later stages of life, but the key to the healing process is finding a suitable adult mentor. Research indicates that normal development is attained by approximately $30 \%$ of the victims surveyed (pp. 88-89).

The book cites interesting data on the implementation of the UN Convention on the Rights of the Child in individual countries (pp. 101-114). A comparative study reveals diverse situations. The most dramatic circumstances are experienced by children in developing countries, or those struggling with armed conflicts. There is also a picture of children and minors as refugees emerging in the world. Without appropriate assistance, claims attorney-at-law Sergio Barbaro, they may become victims of violence and exploitation (pp. 112-116). Despite the positive results already achieved in many places, the implementation of the Convention still calls for considerable efforts.

Cases of sexual offences perpetrated against children and minors, according to attorney-at-law Orazio Moscatello, are to be found in all the countries of the world, irrespective of culture, social class, education, wealth or ethnic origin (p. 121). The data is devastating. For example, in India, the United States and Thailand alone, about 1 million children are introduced to the sex trade every year (p. 122). According to a report written by UN expert Paulo Sérgio Pinheiro, published in 2006, violence against children and mi- 
nors remains largely concealed (p. 127). The reason for this is the victims' fear, social consent to violence, and the lack of reliable and credible ways of reporting such crimes (p. 139). In the case of accusations, one should always seek objective truth. Therefore the established practice of evidentiary proceedings involves examination of individual cases by specialists in the field of law, psychology and psychiatry, together with criminologists and court-appointed physicians. Moscatello states that despite the existence of criminal sanctions for sexual offences against children and minors in almost all legislative systems, the issue is far from resolved. It is not enough to punish the guilty. There is a need to contribute to the "transformation of social mentality and socio-economic conditions conducive to violence" (p. 121). This goal is to be achieved through the education of parents and educators (p. 130).

The last part of the book, containing a practical handbook for the promotion of welfare and protection of children and adolescents and a scheme for conducting educational workshops, is devoted to this very topic. Concise in its content, the handbook describes the competences required for working with children and minors. It also indicates the rules of relationship between adults and pupils and provides safety criteria for conducting classes with minors. The handbook provides examples of typical behaviours of children and minors injured in the sexual context.

The collective work Custodiar la infancia fully deserves the reader's attention. It fills a definite gap that exists in the way the abuse issue is debated. It changes the narrative that dominates within the Catholic Church concerning sexual abuse, which is to recognise the issue and ask for forgiveness. Recognising the problem and beating one's breast are obviously necessary; however, it is equally necessary to analyse the pathological aspects and take remedial steps.

The reviewed book certainly meets these expectations. Reading it may enhance cognitive understanding through a deeper analysis of the issue that is so widely discussed in the media. The sociological method adopted in most articles will give the reader plenty of information about the scale of the phenomenon worldwide. However, one of the book's shortcomings may be a lack of concrete examples, such as first-hand testimonies from victims of abuse; these would almost certainly have a stronger impact than the percentage statistics. A similar problem arises in the presentation of psychological determinants of the relationship between the educator and the educated child. Pointing to such general characteristics as listening, empathy, understanding, assertiveness, or being deprived of a specific human history, will leave readers dissatisfied. 
A major advantage of the work is its formative character, underlined by the inclusion of a practical handbook to help shape the proper relationship between the educator and the child. Based as it is on a healthy Christian anthropology, it will certainly help to better prepare professional and volunteer educators of young people for their work. Custodiar la infancia is recommended to everyone interested in a proper, full and harmonious development of children and youth.

Witold Kania*

ORCID: 0000-0002-9631-8202

Katowice, Poland

\begin{abstract}
Carina Rossa, Viviana Carlevaris Colonnetti (red.), Custodiar la infancia: Promoción del bienestar y la protección integral de niños y adolescentes [Strzec dzieciństwa. Promocja dobrobytu i ochrona integralna dzieci i mtodzieży], Buenos Aires: Editorial Ciudad Nueva, 2018, ss. 170
\end{abstract}

DOI: http://dx.doi.org/10.12775/PCh.2019.034

Początek nowego millenium przyniósł w Kościele katolickim oraz innych środowiskach ożywioną dyskusję dotyczącą bolesnej kwestii wykorzystywania seksualnego dzieci i nieletnich. Po pierwszej fali ujawnienia nadużyć w sferze seksualnej przez ludzi Kościoła w USA za pontyfikatów Benedykta XVI i papieża Franciszka nastąpiły kolejne. Wychodząc naprzeciw temu problemowi, Ruch Focolare stworzył Centralną Komisję ds. Promocji Dobrobytu i Ochrony Nieletnich (wł. Commissione Centrale per la Promozione del Ben-essere e la Tutela dei minori), która opracowała stosowne wytyczne regulujące sferę kontaktów z młodocianymi ${ }^{1}$. Recenzo-

* Witold Kania is an Associate Professor of Philosophy at Faculty of Theology, University of Silesia, Katowice, Poland. He received his doctorate in philosophy from University of Navarra, Pamplona, Spain. His publications include several articles concerning metaethics, ecology and selected issues in applied medical ethics. Contact: Wydział Teologiczny Uniwersytetu Śląskiego w Katowicach, ul. Jordana 18, 40-043 Katowice, Poland. E-mail: witold. kania@us.edu.pl.

1 Zob. https://www.focolare.org/download/linee-guida-focolari-tutela-minori/?wpdm$\mathrm{dl}=171233$ \&ind $=1542193940666$. 